\title{
ÉTICA E JUSTIFICAÇÃO
}

\author{
Ernst Tugendhat**
}

SÍNTESE - Os três artigos seguintes correspondem a três aulas proferidas pelo Prof. Dr. Ernst Tugendhat. No primeiro artigo, o autor trata do conceito de moral em Kant. Na Segunda aula, Prof. Tugendhat concentra-se no problema da liberdade $\in m$ Kant. Por último, no terceiro artigo, aborda o conceito de liberdade como imputabilidade.

PALAVRAS-CHAVE - Kant. Liberdade. Imputabilliade. Determinismo.
ABSTRACT - The following three papers are transcriptions of three lectures by Professor Emst Tugendhat. In the first, he discusses the concept of morality in Kant. In the second, Professor Tugendhat focuses on the problem of freedom in Kant. Lastly, in the third paper, he analyzes the concept of freedom as accountability

KEY WORDS - Kant. Freedom. Accountability. Determinism.

\section{O conceito de moral em Kant}

A discussāo feita na última aula foi talvez saudável, porque me obrigou a caracterizar a problemática em questão mais amplamente e de outros ângulos. Vou fazer três comentários preliminares. O primeiro é, em parte, um resumo de um tema já abordado por mím.

1. Quando caracterizei, há várias aulas, as diferentes maneiras de poder justificar uma moral, distingui, principalmente, a justificaçăo tradicionalista da justificação em relação a motivos que vemos poder pressupor em todos. Ambas as formas de justificaçăo se baseiam em motivos, quer dizer, em um querer, em desejos. Mas numa moral tradicionalista este querer se baseia numa fé transcendental e, à base desta fé, numa subordinação da vontade a uma autoridade: nesse sentido, estas morais são heterônomas. O tipo de moral oposto baseia-se diretamente em motivos naturais - uma possibilidade são as motivações altruístas, mas a dificuldade é, neste caso, que estas motivaçōes não conduzem por si só a um sistema de obrigaçōes. Por outro lado, existe o interesse egoístico de cada um que os outros atuem de uma certa maneira com ele. Isso conduz a um sistema de obrigações mútuas, que é o sistema contratualista. Eu tive e tenho a dificuldade

* São as três últimas aulas ministradas, em portugués, nos dias 4, 11 e 18 de novembro de 1998, no curso Ética e justificação. promovido pelo Programa de Pós-Graduação em Filosofia da PUCRS, patrocinado pelo Conselho Nacional de Desenvolvimento Cientifico e Tecnológico (CNPq) e organizado pelos professores Dr. Ernildo Stein (Pucrs) e Róbson Ramos dos Reis, Universidade Federal de Santa Maria (UFSM).

** Professor da Universidade Livre de Berlim. 
de mostrar que o contrato moral é diferente de um contrato ordinário e negociado. A razãa da diferença é que se trata aqui dum acesso a uma sociedade mantida por obrigações e avaliações mútuas, baseadas em um conceito comum de ser bom parceiro, um conceito que conduz, também, às perspectivas de justiça, de igualdade e de universalidade. Mas isso năo é nada que eu conceba como fácil. $O$ importante, de qualquer maneira, é que a base da moral contratualista é o querer natural das pessoas; é a reunião das vontades naturais (egoistas) das pessoas que conduz a esta moral, porque somos parceiros de uma sociedade moral. A resposta é para cada qual: 1) que eu o quero; 2) que o fato de o querer também dos outros nos conduz a uma justificação mútua que então inclui também a justiça, a igualdade e, possivelmente, a universalidade.

Se alguem pensa que esta justificaçäo näo funciona, que é fraca demais, então tem a opção de, ou estar satisfeito com o contratualismo estrito, ou de tentar buscar uma base mais forte que se situe além da vontade ordinária dos homens. Este segundo caminho é o de Kant - ele achou obviamente que a base contratualista é fraca demais para poder justificar a igualdade e a universalidade (o mesmo ocorre com os Kantianos modernos, como Habermas e Apel). Mas o que não se deve fazer é misturar as diferentes maneiras de justificaçäo. Kant seria o último a permitir isso. Ele pensou encontrar um novo conceito de razão não instrumental que constituiu num a priori e, para ele, era muito claro que justificar a moral dessa maneira, como sendo justificada na razâo a priori, e justificar a moral na base do querer empírico (o contratualismo faz precisamente isso) são duas posições contraditórias e irreconciliáveis. Kant foi um contratualista em sua filosofia política, mas claramente não na moral.

2. Quero fazer referência aqui a uma controvérsia na filosofia analitica atual, que é entre o que se chama internalismo e externalismo de razões práticas. A tese do internalismo é que não tem sentido falar de uma razão prática que năo seja baseada num desejo ou motivo da pessoa para a qual é uma razão. 0 extemalismo afirma que sim - que tem sentido dizer a uma pessoa: tens uma razão para fazer $\mathrm{X}$, sem relacionar isso a um querer da pessoa mesma. Um livro importante para 0 externalismo è o de Thomas Nagel, The Possibility of Altruism (1970), onde já a consideração de meus próprios interesses futuros é vista como um dever racional não baseado na minha motivação. Pode-șe dizer: é irracional não se preocupar com o próprio futuro, enquanto que o internalismo sustenta que a nāopreocupaçäo com o próprio futuro não é irracional, exceto se o indivíduo tem essa motivação. ( 0 . Nagel transfere depois o que ele pensou ter mostrado para o futuro próprio ao altruísmo).

Os externalistas modernos são chamados Kantianos e os internalistas, Humeanos. Mas não é tão fácil classificar Kant como externalista. Considero que se deve dizer que Kant foi internalista e humeano com uma só exceçăo, que é precisamente a moral. Enquanto que os externalistas modernos pensam que pode haver diferentes considerações onde se pode dizer a uma pessoa "é racional que faça X", sem relacionar isto a uma motivação dela, isso para Kant não é possível exceto nesse único caso: existe só um imperativo não hipotético e este é a priori. Kant foi tão profundamente humeano quanto a razões em geral que ele achou necessário, para entender este caso especial, supor uma motivação não natural. Isso va- 
mos ver na próxima aula. A diferença entre as moțvações naturais e as considerações racionais baseadas nelas, de um lado, e a consideração racional, que não está baseada numa motivação empírica, é fundamental para ele. Isso se pode ver muito bem na maneira como Kant introduz seus conceitos na Critica da razão prática.

3. Isso me leva a um terceiro comentário preliminar. Na discussão, pareceu surgir a idéia de que a introduçăo por Kant de seus conceitos e diferenciaçöes na Critica da razão prática fosse mais profunda que na Fundamentaçāo da metafisica dos costumes. Isto não me parece ser assim. A apresentação na Critica da razão prática já é muito mais imanente a seu sistema e não poderia convencer a ninguém que já năo estivesse convencido.

Os primeiros três parágrafos da Crítica da razâo prática têm exclusivamente como tema a distinção entre regras práticas a priori e regras práticas empíricas. Segundo o parágrafo 2 , as regras práticas empíricas são todas materiais, isto é, relacionadas a um fim que se quer, ao objeto do querer (isso é o que é formulado no imperativo hipotético como condiçăo), e (segundo o parágrafo 3) todas estas regras colocam o princípio determinante da vontade na faculdade de desejar inferior e (assim continua no corolário) "se não existissem leis puramente formais (quer dizer, a priorl) que não determinassem a vontade. também não se poderia admitir uma faculdade de desejar superior". Aqui o oponente de Kant, no caso eu, diria simplesmente: realmente é assim, não existe uma faculdade de desejar superior no sentido de Kant, não existe um querer que não se baseia num fim, não existe um querer que não é material neste sentido e, por isso, temos que basear a moral no desejar normal. O próprio Kant explica a alternativa de uma manejra tão categórica que alguém pode decidir segui-la, mas não pode misturar os dois caminhos. A terminologia de uma faculdade de desejar inferior e de outra superior remonta a Ariștóteles, é a diferença entre a motivaçăo por Bom e a motivação por prazer; mas isso significa, para Aristóteles, simplesmente a diferença entre uma ação deliberativa e uma ação diretamente determinada pelo prazer. Também a ação deliberativa, quer dizer, racional, é dirigida ao prazer, mas indiretamente. Evidentemente também Kant conhece a racionalidade como puro meio, isso é precisamente o que se expressa em imperativos racionais hipotéticos. Mas Kant insiste que, se a razão prática não tem um conteúdo próprio, então não existe uma faculdade de desejar superior. Aqui o leitor crítico vai contestar: e que importa? Não seria muito estranho que existisse uma ação que fosse simplesmente racional? A tese expressa no parágrafo 3 da Critica da razão prática é que, se negamos uma tal faculdade de desejar superior, então todos os outros principios práticos "são no seu conjunto de uma só e mesma espécie", quer dizer, materiais e, por isso, baseados em nossa sensibilidade, o que ao crítico parece muito natural. O crítico diria que sim, que há diferenças entre motivações egoístas e moțivações altruistas, mas todas são materiais, e se isto significa, como inșiste Kant, que todas estão baseadas no princípio do amor próprio num sentido amplo, isso pode ser assim, mas não é razão para buscar a base da moral fora deste âmbito. Assim chego à mesma conclusão a que cheguei na última aula, com base na Introduçāo à Metafisica dos Costumes. Vocês não precisam acreditar na minha afirmação, de que fora do âmbito das motivações sensiveis não existe outro querer; vocès podem afirmar que a proposição não hipotética, na Fundamentação, "é racional fazer X" sim, tem sentido ou, formulado como na Crítica da razâo prática, que existe 
uma faculdade de desejar superior, onde a vontade é determinada não por um objeto, mas pela forma de legislaçẫo, que isso tem sentido. Mas o que ninguém deve tentar, porque o próprio Kant o proibiu categoricamente. é misturar as duas coisas, o querer empírico e o suposto querer a priori. Para esclarecer isso, vou supor que exista (o que creio não existir) este querer determinado pela pura forma de uma legislação e, então, pergunto: qual é a motivação de nosso agir moralmente, das nossas relações com os outros homens, das obrigaçōes sob as quais nos pomos mutuamente, ou a obrigação que nos impõe esta razão pura, a pura forma da legislação? Já disse na última aula que, segundo minha interpretaçăo, Kant transpôs a moral da esfera das obrigações mútuas para uma esfera que ele construiu em analogia ao imperativo hipotético - da racionalidade normal - como algo racional puro, que eu considero uma invenção. Mas mesmo que não se considere isso uma invenção, dever-se-ia perguntar se corresponde ao que chamamos obrigação, quando falamos de obrigação moral. Se perguntamos qual pode ter sido o motivo para Kant fazer esta transposição, a grande insistência de Kant na Crítica da razâo prática que somente se as regras morais săo racionais a priori podem ser necessárias e que elas têm que ter uma fonte totalmente diferente de todas as nossas outras motivaçōes, parece-me mostrar que o aspecto da necessidade das regras foi para ele mais importante que o aspecto intersubjetivo e que ele pensou que assim poderia resgatar o caráter de obrigação absoluta que elas tinham tido, quando eram compreendidas de uma maneira teológica. Eu não sou o primeiro que considera a razão pura em Kant como o substituto de Deus.

Posso agora continuar a interpretação da última aula. Kant pensa que ele pode deduzir de "é racional que X" (a forma estrutural do imperativo categórico) que o X tem que ter o seguinte sentido: "Age apenas segundo uma máxima tal que possas ao mesmo tempo querer que ela se tome lei universal". Parece evidente que a afirmação não é válida. A semelhança de que seja uma conclusão correta está na idéia de necessidade. Este aspecto é mais claro na Crítica da razão prática: a oraçäo central ali está no parágrafo 4: "ora, de uma lei, quando se elimina toda matéria, nada mais resta do que a simples forma de uma legislação universal". Mas, corretamente, dever-se-ia dizer que, se se eliminar o contećdo de uma lei ou de um imperativo, nāo sobra nada. É como se eu dissesse 'todos devem' e depois ficasse em silêncio. Kant, quando nảo há conteúdo, transfere a idéia de necessidade para o lugar do conteúdo. Ainda que isso fosse possivel, não seguiria o sentido preciso do conteúdo formal dentro dos parênteses que ele formula. A formulaçăo na Crítica da razão prática é ainda mais próxima ao ponto de partida: o conteúdo formal deve consistir em que a máxima (a regra de ação) possa valer como princípio de uma legislação universal. A formulação na Fundamentação é mais complicada. Por isso, a validez da conclusão é ainda menos óbvia, mas tem um sentido que se presta muito bem ao que conhecemos como as regras morais. Por isso, Kant pôde, com mais ou menos sorte (isso se discute muito), dar, depois da formulação, os famosos quatro exemplos que têm a função de demonstrar que as regras que comumente se considera como morais são consequeências da aplicação de sua fórmula (a assim chamada fórmula 1 do imperativo categórico).

Estes exemplos não são fortuitos, representam, cada um, um dos quatro tipos fundamentais de obrigaçōes que segundo Kant temos: os exemplos 1 e 3, as obrigaçōes negativas e positivas que temos conosco mesmos; os exemplos 2 e 4, as 
obrigações negativas e positivas que temos com os outros. A idéia de poder deduzir de uma fórmula, que parece ter sido feita para as relações com os outros, obrigaçöes para si mesmo, é muito criticada na literatura kantiana. Parece evidente que a aplicação do imperativo categórico não funciona aqui. Não vou entrar aqui em detalhes. Esta dificuldade não é, naturalmente, um argumento contra o imperativo categórico. Poder-se-ia dizer, ao contrário, que é um argumento a favor dele, se não se pode deduzir dele uma regra que não é uma regra moral moderna. Que o suicídio seja proibido, isto é uma regra judaico-cristä, que năo se pode justificar à base de uma moral modema, seja kantiana ou não.

O exemplo central é o segundo, onde se trata da regra de não romper uma promessa. Kant explica, depois dos exemplos, que em alguns casos a universalização nem pode ser pensada - esse é o caso da promessa: se todos sempre rompessem suas promessas, não se poderia mais prometer algo aos outros. Em outros casos sim, pode-se pensar, mas não se pode querer. Este segundo caso é a razão por que a formulação mais curta da Crítica da razão prática - que a máxima tem que ser apta para uma legislação universal - é insuficiente. A formulação mais ampla da Fundamentação, que tem essa referência ao meu querer, é absolutamente necessária. Mas Kant afirma, na alinea depois dos exemplos, que a formulação curta é suficiente para as regras negativas que ele chama de estritas ou perfeitas e a formulaçāo com o querer seria necessária só para as regras positivas (as imperfeitas ou meritórias) que são exemplificadas no exemplo 4, onde se trata da regra da ajuda. Mas Kant cometeu aqui um erro. Não é em todos os casos de regras que caem sob o título de regras negativas, que não podemos conceber sua universalização. Kant estranhamente não se deu conta disso, porque não se perguntou pela razão por que năo se pode pensar sua universalizaçăo, onde isso é assim. A razão é que săo regras institucionais: a promessa é uma instituiçăo que sucumbe, quando não é observada por todos. O mesmo se pode dizer da propriedade: se todos roubam todo o tempo, a instituição da propriedade sucumbe. Mas temos outras regras negativas, onde não se trata de uma instituição como "não deves agredir" ou "não deves causar dores", onde podemos muito bem pensar como seria se todos fizessem isso. Isso não seria um estado impossivel, mas não o queremos. Kant não se deu conta disso, porque usou um exemplo para o caso das obrigações negativas que fol em particular um caso onde se trata de uma instituição. Esta crítica năo é muito importante, mas sublinha a indispensabilidade da palavra querer na formulaçāo do imperativo categórico.

Agora posso dar o próximo passo importante. Se concedemos que a formulação 1 do imperativo categórico, embora não se possa deduzir de forma "x é racional", é uma boa fórmula para a moral, por que nos parece ser isto? Porque é racional ou por que nós o queremos? Aqui estamos outra vez diante da alternativa, da qual eu falei no começo, entre a justificação da moral por ser racional ou porque nós o queremos com nossa vontade empirica. Kant faz aqui um comentário na segunda alinea, depois dos quatro exemplos que eu já citei em parte na última aula: "Se agora prestarmos atenção ao que se passa em nós mesmos sempre que transgredimos qualquer dever, descobriremos que na realidade nāo queremos que a nossa máxima se torne lei universal, porque isso nos é impossivel" (Fundamentação, p. 132). 
É importante ter claro que, quando Kant diz que "na realidade não queremos que a nossa máxima (má) se torne lei universal porque isso nos é impossivel", a palavra queremos se refere a nossa vontade empírica, e que "seria impossível" significa que nos é empiricamente impossivel, porque naturalmente năo queremos (empiricamente) que outros nos tratem imoralmente. Agora, para Kant, esta nota tem simplesmente $\mathrm{o}$ sentido de um esclarecimento. $\mathrm{O}$ fato de que empiricamente não queremos que os outros nos tratem assim nunca pode ser a razão por que é imoral ser assim, pois a razão pela qual algo é imoral é para ele, evidentemente, o fato de ser proibido pela razăo. Segundo minha interpretação, Kant, nesta passagem, aproxima-se muito da compreensāo contratualista, mas isso nāo permite levar a uma confusão do contratualismo com a justificaçăo da moral kantiana. Aqui Kant não dá a justificação, esta foi dada anteriomente, mas nós podemos, baseado nestas passagens, entender por que a formulação 1 do imperativo categórico quase poderia ser entendida como a base de uma concepção contratualista de moral: quase, mas não totalmente. Por que não? Porque o contratualista não tem uma razão de se perguntar em geral quais máximas ele poderia querer que fossem universalizáveis. Ele começa pelo outro lado, perguntando se existem empiricamente certos "males" que todos tratam de evitar; estes "males" são a base de que queremos uns dos outros que observemos certas regras, e essa é a base de cada querer: que estas regras sejam observadas universalmente.

Poder-se-ia pensar que năo faz grande diferença de qual lado se vê a problemática, mas, sim, faz. Para o contratualista, a possibilidade de universalização é somente uma caracteristica necessária, mas não suficiente, das regras morais; estas são, além disso, determinadas por um conteúdo. A formulação de Kant, por outro lado, faz pensar que a pura idéia da universalização é suficiente para gerar as regras morais. Por isso, a formulação kantiana se presta a contra-exemplos, como săo apresentados na literatura (Kant mesmo nunca pensou fazer a prova com contra-exemplos). Por exemplo: 1. eu posso ter a máxima de jantar todos os domingos no melhor restaurante da cidade; esta máxima não é universalizável, pois não posso querer que todos comam no mesmo lugar aos domingos, o que, além disso, nem seria possivel. Segundo o princípio de Kant, essa seria uma razão para dizer que é moralmente proibido atuar segundo esta máxima; mas obviamente não é. Pode-se dar muitos exemplos deste tipo, como o seguinte: tenho a máxima de ir ao trabalho todos os dias no primeiro ônibus, mas eu não posso querer que todos façam isso. Isto demonstra que a formulação 1 do imperativo categórico, embora pareça muito plausível, deve ser suplementada. Este aspecto formal me parece muito menos grave do que a consideração fundamental que mencionei que Kant simplesmente dá uma razão errada porque nós cremos que todos devem obedecer a estas regras, segundo Kant, porque a razão a priori o exige; segundo o contratualismo, é porque nós o exigimos um dos outros reciprocamente.

Agora me resta pouco tempo para alguns comentários sobre as outras duas formulações do imperativo categónico. A segunda diz: "Age de tal maneira que uses a humanidade, tanto na tua pessoa como na pessoa de qualquer outro, sempre e simultaneamente como fim e nunca simplesmente como meio". Essa segunda formulação é, talvez, o aspecto que um maior número de pessoas considera 
muito plausivel na ética kantiana. Apresento, em meu livro sobre ética, uma longa interpretação desta formulação e a forma como se deve entender sua justificação. Aqui só algumas palavras. Onde Kant introduz a formulação, ele não a justifica; apenas faz vảrias afirmaçōes que poderiam parecer dogmáticas: por exemplo, "ora digo eu: os homens existem como fim em si mesmo". Mais adiante (p. 142 da edição da Coleção "Os Pensadores", I. Kant, Textos selecionados, 1980), parece que a verdadeira justificação está implícita na primeira formulação. Não se trata de que o homem é um fim em si mesmo, mas que deve ser tratado como tal, nunca como puro meio; e isto parece significar, se se comparam as explicações que Kant dá nos exemplos, que o outro pode "concordar com a minha maneira de proceder a seu respeito" (p. 136). Isso pode parecer vago, por isso, Kant diz - eu creio que com razão - que a primeira formulação sempre tem que ser entendida como a fundamental. Creio que o contratualista pode aprender algo desta segunda formulaçāo. Por que esta formulaçäo é geralmente - pelo menos isso é minha experiência - aceita como muito plausivel? Creio que é porque todos queremos ser aceitos pelos outros, e como essa é a base das obrigaçães no contratualismo, assim se explica que a regra de não usar a ninguém unicamente como meio é aceita universalmente como obrigação. Poder-se-ia perguntar em que esta fórmula contribui para outras regras especificas. Kant fala em relaçāo com seu conceito de fim em si mesmo, também, do valor absoluto que toda pessoa tem. Valor absoluto é um conceito estranho, soa como uma metáfora; parece mais claro se não dizemos que o homem tem valor absoluto, mas que tem que ser tratado assim e isto, por sua vez, significa simplesmente: não como meio. Queremos, poder-se-ia dizer, uns dos outros que os outros nos tratem como não estando à sua disposição. É isso o que Kant quer dizer quando diz nos exemplos que o outro tem que concordar. Cada um é um ser próprio que não devemos instrumentalizar e isto significa que devemos respeitá-lo, que devemos tê-lo como uma fonte de direitos, que ele tem um direito à nossa consideração. Esta idéia de respeito pode ser entendida como a obrigação fundamental que temos uns com os outros e que está na base de todas as outras obrigações mútuas. Isso se pode muito bem entender de um ponto de vista contratualista, ainda que o contratualismo ordinário não contenha este elemento.

Finalmente, a terceira formulação do imperativo categórico, o conceito de autonomia. Este conceito não conduz a uma formulação do imperativo categórico que é diferente da primeira; por isso, não se pode, na realidade, falar de três formulações. $O$ aspecto da autonomia é simplesmente uma característica que pertence ao imperativo categórico como tal: que essa obrigação não é uma obrigação a que eu somente estaria subordinado, mas é uma obrigação que eu mesmo me dou - é uma autolegislação.

Por que é assim para Kant? Porque a vontade dos homens é, como ele diz, ela mesma racionalidade prática. O imperativo categórico diz o que é racional fazer, isso quer dizer o que eu mesmo quero, enquanto me compreendo como eu racional. Noutro lugar, Kant afirma: "este dever é em realidade um querer". Mas deveremos dar-nos conta de que os conceitos aqui essenciais - de querer, de vontade, de eu - são todos ambíguos em Kant. O ser que Kant considera aqui autônomo 
não é o homem, mas somente o homem enquanto é racional. Não se trata da vontade que pode ser racional ou irracional - e Kant chama esta vontade, para evitar essa ambigüidade nos escritos posteriores, de arbítrio - WillküI - mas aquela vontade que já é determinada pela razão. Poder-se-ia explicar isso com os termos de Freud, embora, em seu conteúdo, a racionalidade ou vontade racional não se possa identificar com o superego. Mas não obstante a autonomia da qual Kant aqui fala não ser uma autonomia do eu, do homem, mas do que corresponderia ao superego, de qualquer maneira não do querer como tal, mas de um querer qualificado, do querer racional. Näo é o homem que é autônomo, mas uma parte dele. Essa problemática do conceito de autonomia em Kant foi forte e talvez exageradamente criticada no livro de R. Bittner Moralisches Gebot und Autonomie (1983). Bittner se queixa que não é o eu ou o homem que é autônomo em Kant, e já Schiller e Hegel tiveram esse problema (e naturalmente eu também o tenho).

Como é o problema da autonomia na moral contratual? Aqui sầo os próprios homens, no seu querer empirico, que fazem exigências e se subordinam mutuamente às regras. Assim se gera o que se pode chamar uma autonomia coletiva. Cada um é, se o sistema é justo, tão livre como todos os outros. Enquanto que em Kant só uma parte do homem é autônoma e a outra tem que se subordinar, para o entendimento contratual, todos são, como num jogo, fontes autônomas e ao mesmo tempo se subordinariam às regras - quer agora dizer mutuamente, não é a razăo ou um eu racional que manda, mas somos nós mesmos, enquanto queremos uma coordenaçăo reciproca.

\section{O conceito de liberdade em Kant}

Hoje vou tratar do problema da liberdade em Kant. O conceito de liberdade é ambíguo. Pode-se começar dizendo que uma pessoa é livre quando pode fazer o que quer; mas aqui se pode fazer a seguinte distinção: a ação da pessoa é livre quando faz o que ela quer, mas é também livre o querer mesmo? No problema da liberdade politica, esta segunda pergunta não importa, mas na psicologia, na filosofia moral e na filosofia legal sim é importante: não é suficiente saber se a ação da pessoa é livre, livre porque baseada em sua vontade, mas se quer saber se a vontade mesma é livre, porque, se não é, não poderíamos dizer que a pessoa é responsável por sua ação, responsável num sentido de imputabilidade. Também um animal ou uma criança pequena tem liberdade de ação, pode, se não está coagida, fazer o que quer, mas supomos que só as ações de uma pessoa são livres no sentido de imputáveis.

A fórmula que se usa para este fenômeno (e que se encontra também em Kant) é que poderia ter agido de outra maneira. O problema da liberdade é, então, como se tem que entender este fenômeno? Desde o começo da filosofia cristă, isso apareceu problemático, para a perspectiva cristã devido à idéia da presciência de Deus. Se Deus sabia tudo que iria passar desde sempre, como se pode dizer que é indeterminado no sentido que é a pessoa que vai determiná-lo; que é ela que o determina, isto é, que ela teria podido determiná-lo de outra maneira. 0 mesmo ocorre na época moderna em que todos estão mais ou menos convencidos de que tudo está predeterminado por leis, pela causalidade natural. Se uma ação 
de uma pessoa está determinada pela causalidade natural, como pode ser ela imputável pelo que fez, como podemos dizer que depende dela o que fez se depende das causas naturais anteriores?

Isso é o problema da liberdade da vontade que Kant já discute e que se segue discutindo hoje. Distinguem-se duas escolas: a compatibilista e a incompatibilista. A compatibilista diz que a causalidade e a liberdade não se excluem, que a liberdade è simplesmente uma maneira de comportamento causado. $\mathrm{O}$ incompatibilismo diz que, enquanto uma ação é determinada por mim, não pode ser (ou não pode ser vista) como causada. Enquanto que o incompatibilismo é defendido hoje, está sempre em perigo de ter que admitir que a liberdade é uma coisa de acaso, porque se a liberdade não é compativel com a causalidade ela pareceria como um buraco na causalidade. Um buraco na causalidade seria uma coisa de acaso, mas se a ação è o produto de um acaso, não poderíamos considerar a pessoa responsável.

Kant pensa poder sair da alternativa de compatibilismo e incompatibilismo da seguinte maneira: um resultado de sua filosofia teórica foi que o mundo da natureza, do tempo e espaço e da causalidade é somente o mundo como se nos pare$\mathrm{ce}$, e isso, segundo ele, deixa aberta a possibilidade de que se pode conceber desse mesmo mundo como é em si mesmo, como mundo inteligivel; mas deste mundo inteligível não sabemos nada. Ainda que não saibamos nada dele, Kant pensa que poderia ser que o que experimentamos como liberdade poderia ser algo que pertence a este outro mundo. Disso resulta que Kant é, ao mesmo tempo, incompatibilista e compatibilista. Incompatibilista, enquanto no mundo sensivel, no mundo natural, a causalidade, segundo ele, exclui a liberdade; mas somos livres enquanto somos membros do mundo inteligível, embora sejamos não livres, enquanto membros do mundo natural. Năo conheço ninguém que creia nesta distinção entre mundo natural e mundo inteligível; eu mesmo näo acredito nas razões que Kant dá na Crítica da razão pura para esta diferença - intimamente ligada com a teoria dos juizos sintéticos a priori. Mas em minha crítica ao conceito de liberdade de Kant vou supor que ele esteja perfeitamente justificado em fazer esta distinção. Esta distinção não vai ser parte de minha crítica. Vou supor, entăo, que Kant está legitimado em fazer esta distinção e a pergunta vai ser se ele consegue explicar o fenomeno da liberdade baseado nesta suposiçäo.

Mas antes de entrar nisso, deveremos dar-nos conta de que Kant foi obrigado a apresentar um segundo conceito de liberdade. 0 que 0 obrigou a conceber um segundo conceito de liberdade e precisamente seu estranho conceito duma razâo prática a priori, que, como tentei mostrar nas últimas duas aulas, considero ser uma invenção. Este segundo conceito de liberdade, que para Kant vai ser o primeiro (a base do outro) e que, em geral, não se conhece, porque é somente a consequência do estranho conceito de razāo prática pura, è introduzido na Fundamentaçäo da metafísica dos costumes mais cautelosamente que na Crítica da razão prática. O texto que devemos entender primeiro è aquele que vem ainda antes da primeira fómula do imperativo categórico e que é introduzido assim (127): "Surge agora a questão: como são possiveis todos estes imperativos" (quer dizer o hipotético, o assertórico e o categórico)? Com esta pergunta "como são 
possiveis", Kant quer esclarecer, como ele diz imediatamente, de que maneira se tem que entender a "obrigação da vontade que o imperativo exprime". Talvez isso ainda não esteja talvez totalmente claro. $\mathrm{O}$ que Kant quer dizer é, como é possível que o imperativo obrigue a vontade, $e$ isso significa como se tem que entender 0 correspondente querer (se nāo fosse compreensivel como um querer se pode submeter ao imperativo, o imperativo mesmo ficaria obscuro - isso tem que ver com a convicção justa de Kant que todo dever pressupõe um poder, um poder querer). Agora ele diz que é fácil responder a esta questão de como é possível, no caso do imperativo hipotético, mas no caso do imperativo categórico nos vemos, diz Kant, confrontados com um grave problema, que faz com que tudo o que se diz sobre o imperativo categórico na segunda seção fique hipotético até poder responder a esta pergunta: "Por que esta diferença entre a possibilidade do imperativo hipotético e o imperativo categórico?"

No imperativo hipotético, Kant vê a situação assim: "Quem quer o fim, quer tambèm o meio indispensavelmente necessánio para o alcançar, que esteja no seu poder. Esta proposição é, pelo que respeita ao querer, analítica." Agora é importante que Kant pôs um parêntese nessa oração em que diz ("se a razão tem influência decisiva sobre suas açöes"). Isso significa que a oraçã̃o sem este parêntese não é analitica: eu posso querer o fim, mas se não me subordinar às consideraçōes da razão, nảo vou querer o meio. Por exemplo, tenho dores de dente, quero que estas dores cessem; é razoável ir ao dentista, mas se os sentimentos do momento predominam em vez da racionalidade, não vou ao dentista. Então, temos: (1) se quero $Y$, e (2) se a razão tem influência decisiva sobre minhas ações, vou fazer $X$.

Se expusermos a situação no imperativo hipotético desta maneira, nós temos que perguntar: por que a situação no imperativo categórico não é perfeitamente análoga? Análoga significaria: $1^{\circ}$ que naturalmente a primeira premissa fica suprimida e $2^{\circ}$ que o sentido da razão muda, no caso do imperativo hipotético e a razão instrumental, no caso do imperativo categórico e a razão a priori. Teriamos, então: se a razão ( $a$ prion) tem influência decisiva sobre mim, vou fazer $\mathrm{X}$ (vou-me comportar moralmente). A primeira vista, o leitor não entende que não se pode ver a coisa assim. A resposta se encontra na nota 28 (p. 129): "Eu ligo à vontade, sem condição pressuposta de qualquer inclinação, o ato a priori..." E no texto, ele diz que se trata de uma preposição sintética a priori. Estamos aqui diante do que Kant considera o ceme do problema da razão prática pura. Como ele dirá na terceira alínea da terceira seção, uma proposição sintética precisa de um terceiro fator que combine os dois termos e este terceiro termo é, nesse caso, a liberdade.

Como entender tudo isso? A razão por que Kant pensa que não se pode dizer simplesmente que eu posso querer ser racional (no sentido de razão a priori) é que a vontade e a pura razão não se podem combinar no mundo fenomênico, "sem condição duma inclinação". Um ato de racionalidade pura não é possivel em nosso mundo, porque toda vontade depende duma inclinação. Isso é o ponto que já antecipei na última aula. Kant é tão profundamente humeano, que uma razão pura nāo nos pode influenciar, exceto se se diz que somos também membros de um outro mundo que é livre da sensibilidade. 
Esse, então, é o segundo conceito de liberdade em Kant e o que, para ele, seria o primeiro - um querer que é livre da sensibilidade. Para o crítico de Kant, essa consequência de seu conceito de racionalidade pura naturalmente torna este conceito ainda mais estranho: primeiro, Kant inventa esta concepção duma obrigação baseada em pura racionalidade - isso já é suficientemente estranho em si - e, segundo, isso o obriga a supor que a vida prática do homem só pode entender-se em parte pertencente a outro mundo, um mundo năo sensivel, e é isso que ele agora chama uma vontade livre. Não se trata, no momento, do fenômeno de se têr podido agir de outra maneira, do conceito de liberdade no primeiro sentido, mas duma equação nova: vontade racional igual à vontade livre da sensibilidade, livre de fatores do mundo fenomênico. $\mathrm{E}$ em que sentido isso pode esclarecer também o outro conceito de liberdade - o conceito da imputabilidade - teremos que ver depois. No momento, este outro conceito não aparece e não aparecerá em toda a Fundamentação da metafísica dos costumes.

O resultado desta reflexão de Kant sobre como é possível um querer segundo o imperativo categórico é que ele diz que toda a moral que ele desenvolveu na segunda seção somente faz sentido se podemos supor que temos esta liberdade, se podemos supor que o homem não é somente um habitante do mundo natural, mas também do mundo numênico. 0 próximo passo de Kant está nas primeiras duas alíneas da terceira seção, que correspondem aos parágrafos 5 e 6 da Crítica da razâo prática. Em ambos os casos, Kant crê poder demonstrar duas coisas: primeiro, o que já sabemos, que a vontade racional só é possível como uma causalidade năo sensivel; como liberdade nesse sentido, é também; segundo, vista do outro lado, uma causalidade não fenomenal, uma causalidade livre que tem de ser entendida como determinada pela razão, pela lei da razão. A maioria das pessoas nāo se dá conta que Kant pôde demonstrar isso so à base de uma suposição que não se entende por si mesma. Eile diz, na Fundamentação, que o conceito de causalidade em geral "traz consigo o de leis: a liberdade por isso não é desprovida de lei, mas tem antes que ser de uma causalidade segundo leis imutáveis". Ele explica: "pois de outro modo uma vontade livre seria um absurdo". Isso é verdade, mas dizer que "o conceito de causalidade como tal traz consigo o de leis" é muito problemático, porque, na Crítica da razâo pura, Kant sustenta que o aspecto de lei entra somente no conceito sensivel de causalidade; além disso, na maneira como Kant explica a categoria pura, no capítulo da causalidade sobre "Phenomena e Noumena" e ainda na terceira Antinomia, esse conceito näo contém nada de leis. Como podemos supor que sobre as coisas em si, acerca das quais, segundo Kant, não sabemos nada positivamente, podemos dizer que são determinadas por algo como lei?

Mas vamos conceder tudo isso a Kant. As verdadeiras dificuldades estão em outra parte. Não vou me ocupar do problema da terceira seção que é o seguinte: com que direito podemos afirmar que esta liberdade, que desde o ponto da filosofia teórica é só uma possibilidade lógica, existe. Esta problemática levou Kant depois, na Crítica da razão prática, à doutrina, segundo a qual é a lei moral mesma que é a base do nosso conhecimento da liberdade, que esse é um conhecimento puramente práticó e que a consciência da lei moral é um fato (o único fato) de razão. 
Mas esses são problemas internos. O verdadeiro problema consiste em entender como a suposta causalidade năo sensivel pode ter uma eficácia em nosso mundo sensivel ou, dito de outro modo, como ela é compativel com a causalidade natural $\mathrm{O}$ que significa, concretamente, que a vontade racional (ou moral) tem que ser entendida como numenal? À primeira vista, poder-se-ia pensar que um ato de pura racionalidade ou da vontade boa seria como um raio que cai no meio dos atos da vontade sensivel. Mas isso é evidentemente impossivel, pois a causalidade natural é densa, não deixa aberturas para uma causalidade do outro mundo. Cada acontecimento no mundo natural é, segundo Kant, o efeito da causalidade anterior e isso o explica completamente. Naturalmente surge também a pergunta: como entender a má vontade, a vontade de nào obedecer à obrigação supranatural? Onde acontece isso? Existe um eu entre a causalidade natural e a causalidade racional que se decide a agir segundo isso ou segundo aquilo? Essa seria a liberdade no primeiro sentido exposto, isto é, o de poder fazer ou não fazer alguma coisa. Mas se fosse assim, a qual dos dois mundos pertenceria este eu?

Todas estas opçōes são, com razão, rejeitadas por Kant, pois elas conduziriam a contradições. Em vez delas, Kant fez uma construção diferente, exposta mais explicitamente na terceira Antinomia do Crítica da razão pura, mas, como agora vamos ver, esta construção não explica a eficácia do fator racional no mundo sensivel e penso que também é contraditória. A intuição fundamental de Kant é que, como nāo se contradiz que as coisas, mais precisamente aqui as pessoas. têm um aspecto fenomenal e tambem uma aspecto numenal, não se contradiz que, por um lado, elas são totalmente determinados pela causalidade natural $\mathrm{e}$. por outro lado, são totalmente livres dela.

Poder-se-ia entender essa não-contradição, se os dois lados ficassem independentes um do outro. Mas Kant afirma que o objeto em si mesmo nāo é somente $o$ outro lado do objeto como fenômeno e não somente é o fundamento do lado fenomênico, mas pode ser entendido como a causa: existe uma relação causal do noumenon sobre o fenômeno: o fenômeno é o efeito do noumenon. Poderse-ia questionar esta afirmação de Kant (que é possivel supor uma relaçäo causal entre o noumenon e o fenômeno), mas vamos conceder-lhe também isso, e vamos introduzir imediatamente como Kant concebe esta relação. Aqui ele introduz (B 566s) os conceitos de caráter inteligivel e caráter empírico. Ele dá uma explicação formal do conceito "caráter" de uma coisa - diz que é a lei de sua causalidade mas entende este fenômeno também no seu sentido normal psicológico. O caráter empírico de uma pessoa é a disposição que tem sua vontade empirica de atuar de uma certa maneira. Acerca deste caráter empírico, Kant afirma que, sendo um fenômeno, ele e por isso todas as nossas ações são totalmente determinadas pela causalidade natural. "Todas as ações do homem no fenômeno estão determinadas, segundo a ordem da natureza, por seu caráter empírico e por todas as outras causas coatuantes. No que diz respeito a este caráter empírico, pois, não há qualquer liherdade." Não obstante a base da obrigação em que nos vemos pela moralidade, isto é, a razão pura, podemos dizer que poderíamos ter agido diferentemente.

Não é isso uma contradição, se o caráter está totalmente determinado? Não, diz Kant, porque podemos conceber que o caráter empírico é, por sua vez, causa- 
do pelo caráter inteligivel, que nảo está submetido à causalidade natural nem ao tempo e que podemos conceber como livre. O caráter empirico é o "esquema sensual", diz Kant em B 581, do caráter inteligivel e "cada ação consiste [sem levar em conta a relação temporal na qual está com outros fenômenos] o efeito imediato do caráter inteligível da razão pura". Para esclarecer isso, Kant dá o famoso exemplo de uma "mentira maldosa". Kant diz que ela pode ser explicada (pelo menos em teoria) completamente pelas causas precedentes: devido a um mau ambiente etc., mas, por outro lado, "nem por isso admoesta-se menos o agente... pois pressupõe-se que é possivel pôr totalmente de lado a natureza de sua conduta anterior... e de encarar este ato como totalmente incondicionado." "A ação é atribuída ao caráter inteligivel do homem, e agora, no momento em que mente, ele é totalmente culpado; portanto, desconsiderando todas as condições empíricas do ato, a razão é integralmente livre e a mentira é totalmente imputável à sua omissão."

Essa é, pois, a teoria de Kant sobre o modo como se deve conceber a relação entre a liberdade e a causalidade natural na ação humana. Vou comentá-la passo a passo.

Primeiro, o exemplo que acabo de citar. Kant se baseia aqui, quanto ao juizo da liberdade da ação, puramente no fato de que julgamos assim. Mas se se supōe, como Kant 0 faz, que $o$ ato foi totalmente determinado, parece pura crueldade e desumanidade dizer que o homem pôde não ter cometido o ato. Se se concorda com a posição de Kant, de que o ato foi totalmente determinado, não seria mais justo concluir que o juizo - que ele poderia ter agido diferentemente - está errado e que toda a teoria da moral que Kant pressupõe também está errada?

Segundo, passo ao problema conceitual. Kant insiste que o homem poderia ter agido de outra maneira, porque o seu caráter inteligível poderia ter sido diferente. Suponhamos que assim o fosse. Como o ato concreto da mentira, ou qualquer outro ato no mundo fenomênico, foi, segundo Kant, totalmente determinado pela causalidade natural, como é pensável que a suposta liberdade numênica poderia ter feito uma diferença no mundo fenomênico? Como se pode dizer que o homem poderia não ter mentido, se a mentira foi a conseqüência necessária das causas naturais anteriores? Este é o ponto, no qual não se entende a eficácia que teria a liberdade numênica para o mundo fenomênico. Se ele não pôde agir de outra maneira por causas fisicas, então é contraditório dizer que à base do caráter inteligível poderia ter agido de outra maneira. A concepção de Kant, de que a liberdade e a necessidade causal não se contradizem, porque a liberdade é inteligivel e a necessidade é fenomênica, não é convincente, porque a liberdade numenal somente teria um sentido no mundo fenomênico se fizesse uma diferença neste mundo.

Terceiro, Kant insiste que o caráter inteligivel é atemporal (e isso naturalmente é uma conseqüência necessária do caráter do tempo, que è uma forma concernente apenas ao mundo fenomênico). Mas o que significa uma liberdade atemporal, uma liberdade que não é uma liberdade neste momento? (Kant diz, por exemplo, que, neste momento, o homem poderia ter não ter mentido). Na Elucidação Crítica da Analítica da Crítica da razão prática, Kant parece dizer que o caráter empírico, junto com todo o passado que o determina, tem uma unidade 
determinada pelo caráter inteligivel: "toda a cadela de fenômenos" depende da unidade dum ato voluntário inteligivel. Isso naturalmente so gera novos problemas. Seria contraditório, como o mesmo Kant pensa a liberdade do homem, supor que uma única decisão atemporal determinaria sua vida. Em outros contextos, em particular na sua obra sobre a Religião, Kant insiste que o homem deve, em cada momento, melhorar seu caráter; isso naturalmente pressupōe que em cada momento se precisa de um novo ato livre. Parece-me evidente que o recurso a um mundo atemporal é totalmente inadequado para esclarecer o que entendemos por liberdade, que é algo essencialmente temporal.

Quarto, até agora não considerei o fato de que Kant, na terceira Antinomia, como também na Elucidação da Crítica da razão prática, combina os dois conceitos de liberdade. Na terceira Antinomia, fala da "razão", mas, com isso, obviamente não pensa somente na razão como tal, nem só na decisăo racional (isto é, moral), mas na decisão do arbítrio humano em relação à lei moral. O caráter inteligivel que cada homem se dá, segundo Kant, a si mesmo, è uma atitude boa ou má em relação à obrigação. O caráter inteligivel de cada um contém este fator de decisảo. É desta forma que Kant responde à minha pergunta sobre onde fica o eu que decide ser bom ou mau. Isso significa que Kant transpôs esse fator do arbitrio ao caráter inteligivel. $\mathrm{Na}$ obra sobre a religiäo, Kant explica que o arbítrio de cada homem tem que decidir sobre a ordem hierárquica em que ordena as duas leis - a lei moral e a lei do amor próprio. Essa é, em si, uma concepção interessante, mas o problema está em transpor o sujeito desta decisão ao caráter inteligivel. Aqui se tem que perguntar: se o sujeito do arbítrio pertence à região intelectual, como ele pode decidir sobre sua relação ao amor próprio? É então o caráter inteligivel que é mais ou menos egoístico. Mas o problema mais grave que surge aqui é o de como conciliar esta caracterização do caráter inteligivel com a afirmação, com a qual Kant começou a sua teoria de liberdade, de que só se pode entender uma vontade livre como uma vontade sob uma lei, a lei da razão pura. Isso se baseou na idéia de que somente a vontade racional, a vontade boa é livre. Mas, agora, Kant está pensando na liberdade entre o bem e o mal, e essa vontade, se é livre, tem a capacidade de ser contra a lei da razão.

Conçluo que a teoria da liberdade de Kant está cheia de dificuldades insolúveis. O que está na base dessas dificuldades? Em primeiro lugar, seu conceito de razâo pura. Foi este conceito que conduziu à idéia de uma liberdade que consiste no estar livre de motivações naturais, e este conceito de liberdade me parece estar tāo longe da realidade da ação humana, que, em primeiro lugar, nảo se pode combinar com a causalidade natural e que, em segundo, conduz a mais dificuldades quando se combina com o outro sentido de liberdade, que é o seu sentido normal - o de ter podido agir de outra maneira.

Na terceira Antinomia, Kant expõe sua teoria com muita confiança. Ao fim da elucidaçāo da Crítica da razāo prática, seis anos mais tarde, é mais modesto. Diz: (eu cito numa traduçäo nova do prof. Valério Rohden, no prelo) (184): "Dir-se-á que a aqui exposta resolução da dificuldade encerra muitos obstáculos internos e não é sequer suscetível de uma apresentação clara. Mas por acaso alguma outra que se tentou ou possa tentar é mais fácil e compreensível?" 
Na próxima aula vou tentar mostrar que, se rejeitarmos a ideia duma liberdade supra-empírica, vai-se poder entender muito melhor 0 que naturalmente entendemos sob imputabilidade, ainda que não vou pretender que a minha concepção näo tenha também dificuldades.

\section{O conceito de liberdade como imputabilidade}

Quero apresentar hoje uma alternativa à concepção kantiana de liberdade. Há algum tempo, publiquei em alemão um artigo com o título "Sobre o conceito da liberdade da vontade" e, em parte, as minhas reflexöes vão corresponder a este artigo.

Vamos primeiro esclarecer a questão que tratamos aqui. Uma parte da problemática de Kant simplesmente desaparece com o conceito de razão pura. 0 problema que permanece é o problema da responsabilidade no sentido de imputabilidade, isto é, a possibilidade de dizer aos outros e também a si mesmo: tu foste a causa disto, tu és responsável. Como podemos dizer "tu foste a causa", se, por outro lado, cremos que tudo está num nexo causal? Se uma pessoa foi a causa, esta causa é, por sua vez, o efeito de outras causas, como, por exemplo, das motivações desta pessoa, e estas motivações são, por seu turno, efeitos dos eventos anteriores, como, por exemplo, dos genes, da educação etc.. Eu já disse no começo da aula anterior que o fenômeno da imputabilidade é caracterizado (também por Kant) pelo fato de se poder dizer que o agente "poderia ter agido de outra maneira". Que sentido tem dizer que a pessoa poderia ter agido de outra maneira, se ela somente é o efeito de outras causas e se parece ter sido necessário agir assim? Em que sentido existe um espaço aberto que corresponde a este "poder ter agido diferentemente", que está pressuposto quando falamos de imputabilidade?

Já dișse no começo da última aula que as duas correntes filosóficas que enfrentam este problema são o compatibilismo e o incompatibilismo. O compatibilismo diz que o ser imputável é simplesmente um tipo de comportamento causado, que causalidade e liberdade são compativeis, enquanto que o incompatibilismo insiste, assim como pensou Kant, que o ser imputável, o ser livre exclui o estar causado. Como hoje ninguém segue a Kant na suposição de um outro lado do mundo, o numênico, para explicar a liberdade, isso significa que os incompatibilistas modernos como Chisholm supõem espaços não causais dentro do mundo causal. Mas penso que a idéia de que a liberdade implica acausalidade parece claramente errada, porque, se não pensássemos que a ação de uma pessoa tem a ver com seu caráter, que tem uma certa causalidade, năo lha imputariamos. A única maneira que temos de conceber a causalidade dentro de um campo causal é o acaso, e se tivéssemos que imputar a ação ao acaso, não a imputariamos à pessoa. Assim, parece-me que o incompatibilismo como explicaçăo da liberdade não é uma opção séria.

Existe uma terceira corrente, cujos representantes, de um lado, têm uma concepção incompatibilista, mas que pensam que isso não se pode demonstrar positívamente e, por isso, têm uma posiçâo cética, dizendo que, num mundo completamente determinado, a liberdade não existe. Essa posição se aproxima do fatalismo que vou caracterizar mais adiante. No direito penal alemão (não sei como é 
aqui no Brasil), muitos autores defendem uma posição agnóstica, dizendo que a imputabilidade pressupõe liberdade e que liberdade é um conceito metafísico; e como năo sabemos se podemos supor que o réu foi imputável, toda a lei penal se baseia numa hipótese metafísica. Não simpatizo muito com essas posições céticas e agnósticas, porque elas pressupõem um conceito de liberdade metafísico.

Eu parto do fato de que liberdade e imputabilidade são conceitos de nossa vida, e que por isso năo podem ter um conceito recôndito. O problema da imputabilidade para mim consiste em simplesmente encontrar criterios que mostrem quando consideramos uma ação imputável e quando não. Isso já fez. Aristóteles no livro III da Ética. Ele primeiro dá como critérios de uma ação voluntária em contraste com a involuntária: (1) que ela não deve ser por coação, e (2) que o sujeito deve ter conhecido as circunstâncias de sua ação. Esses critérios são válidos ainda hoje: se a pessoa foi coagida por outros a fazer o que fez, não é ela que é imputável e o único elemento que uma teoria moderna vai ter que acrescentar é que existe também o fenômeno da coação interna, da compulsão psíquica. Depois, Aristóteles diferencia entre uma ação sem deliberação e com deliberação, não tirando, porém, as consequências disso para o conceito de imputabilidade, nem confrontando o problema com algo que ainda não the era conhecido, a saber, a nossa convicção de causalidade geral. Repito que eu creio que a liberdade, no sentido da imputabilidade, é um fenômeno da nossa vida ativa e intersubjetiva e por isso não tem que ser provada, senão esclarecida.

Antes, porém, de empreender tal tarefa, quero esclarecer quais são as regiões em que nos deparamos com este fenômeno. A maior parte da filosofia, no passado e hoje também (Kant é somente um exemplo extremo), fala como se a região primária desse fenômeno fosse a moral. Na filosofia anglo-saxônica se fala ainda de responsabilidade moral. Isso me parece um erro. Uma segunda região onde a suposição de que a ação é imputável e igualmente importante é o direito penal. Todo o direito penal modemo parte da suposição de que o autor é responsável por sua ação, caso pudesse tê-la evitado. Mas uma terceira região é a relaçăo comigo mesmo, quando posso fazer-me repreensöes na vida cotidiana, dizendo a mim mesmo: por que näo tiveste mais cuidado, por que não pensaste nesse perigo, neste bem ou nesta chance? Também amigos podem falar assim uns com os outros ou, por exemplo, os pais com seus filhos, por exemplo: "quando cruzaste a rua não somente devias pensar em chegar ao outro lado, mas ter cruzado refletidamente, tendo em mente os diferentes possiveis males do tráfego". Aqui se fala num dever que ainda não é um dever moral e não um dever legal, mas que tem o sentido fraco de um dever relacionado ao meu próprio bem. Fiquei, por exemplo, na cama tempo demais, porque era tăo agradável e, por isso, esqueci as coisas importantes que deveria fazer esta manhã. Depois me repreendo: foi por minha propria culpa que perdi essas reuniōes etc. Qual é o objeto de minha repreensăo? Aparentemente minha capacidade de refletir, de deliberar. Podia ter liberado mal ou pouco ou simplesmente não. Parece ser esta capacidade de deliberaçăo que é o objeto primeiro da educação, também da auto-educação, talvez assistida por una psicanálise que tem a tarefa de ampliar nossos espaços de liberdade. 
Considero que o fenômeno da imputabilidade deve ser agora elucidado, em primeiro lugar, nesta terceira região, por duas razões: primeiro, porque aqui já é o mesmo fenômeno, mas não complicado por preconceitos que podemos ter quanto ao direito e, em particular, quanto à moral. Segundo, porque se pode mostrar que a imputabilidade da qual se fala no direito e na moral são redutiveis a essa imputabilidade para consigo mesmo. Pois os mandamentos da lei da moral são para o indivíduo simplesmente outros fatores da sua situação que ele pode entender como bens ou como males para ele e que ele pode tomar em conta igualmente como os outros fatores - os outros bens e males - da sua situaçăo de deliberaçāo. Se o individuo se identifica com uma norma moral ou com uma norma legal, isso significa que ele vai considerar esta norma como um fator bom para si mesmo. Se não se identifica com essa norma, ele tem que ter em conta, na deliberação de sua situação, que a infração desta norma tem como conseqüência uma sanção social um castigo penal ou a indignaçāo - e esta sançâo vai figurar como um mal para ele entre os outros fatores da situação. A perspectiva da lei penal e a perspectiva da moral têm facilmente a tendência de apresentar a situação da liberdade da pessoa em preto-e-branco: se faz o que tem que fazer, a pessoa é boa, se não, é má. Mas se a pessoa aceita esta maneira de pensar, ela se comporta de maneira heterônoma; se é autônoma em sua decisão, os fatores legais e morais da situaçăo são somente certos bens ou males para ela, entre outros. Desde seu próprio ponto de vista "deve" escolher o bem melhor ("deve" no sentido de sua prudência); quer dizer que possivelmente (não necessariamente) "deve" dar precedência a outros fatores que ao "dever" moral ou legal. Uma pessoa que age de acordo com seu próprio ponto de vista pode ser chamada de autônoma. Isso é a autonomia do eu em contraste com a idéia de autonomia kantiana. Essa autonomia do eu corresponde a um certo conceito de liberdade. Este sentido não é idêntico com a imputabilidade, mas está fundado nela e é um fenômeno gradual. Uma pessoa autônoma é mais livre - faz mais o que ela mesma quer - do que uma pessoa para a qual certos tipos de razōes (inclusive as morais) já contêm em si uma necessidade prática e não são consideradas como puros elementos na situação de decisão. Isso naturalmente seria um horror para Kant. Poderiamos dizer que a este conceito de liberdade corresponde um conceito de consciência de culpa que se distingue da culpa moral. Seria (como o propōe Fromm) um conceito de consciēncia autônoma. A pessoa que age mal em relação às obrigações do sistema moral, do qual ela se considera como membro, tem normalmente um sentimento de culpa moral. A pessoa que age mal em relação à hierarquia de seus próprios valores teria um sentimento de culpa autônomo, ou talvez, como năo é intersubjetivo, não devêssemos falar de sentimento de culpa, mas a pessoa o sente como deplorável e vai repreender-se a si mesmo.

Mas voltemos ao conceito de imputabilidade e tentemos esclarecê-lo estruturalmente. Como primeiro passo, vou apresentar a teoria de G. E. Moore em sua Ética (1912). Moore tenta nessa obra esclarecer o fenômeno de "poder ter feito diferentemente". O que Moore tenta mostrar é que esta expressāo pode ter um sentido muito inocente que não implica nenhuma contradição com a causalidade natural. Ele dá o seguinte exemplo: eu teria podido correr nesta manhã $5 \mathrm{~km}$ em 1 
minutò. Moore indica o simples fato de que a palavra poder tem dois sentidos diferentés. Ainda que eu pudesse ter feito, neste sentido de "poder", uma coisa que não fiz (não corri), tudo o que fiz foi causalmente determinado e, neste sentido, necessário e, por isso, não poderia ter sido de outra maneira. Moore chama, assim, a atenção para o fato de que, na expressão "poderia ter agido de outra maneira", a palavra poder não é compreendida em oposição à necessidade, mas à incapacidade. Era incapaz de correr $5 \mathrm{~km}$ em 1 minuto, mas era capaz de correr 5 $\mathrm{km}$ em 20 minutos, embora não tenha corrido. O "poder diferentemente" do qual se fala, quando se fala de imputabilidade, näo está em contradição com o não poder fazer uma coisa contra a necessidade das leis naturais.

Este primeiro passo demonstra que temos aqui um sentido de "poder ter agido diferentemente" que e um fenômeno muito geral e que não se refere somente aos seres vivos. Por exemplo, este copo pode quebrar. Isso se define assim:

1) em tais e tais circunstâncias o copo quebra (1).

Temos agora que ver como este conceito se aplica a uma ação humana. Aristóteles indica, no livro IX da Metafísica, uma diferença entre capacidades de seres vivos sem vontade e com vontade. Um carro, por exemplo, pode correr. Isso significa que corre, se está em tais e tais circunstâncias, se tais e tais outros fatores causais se combinarem com ele, por exemplo, se se aperta o acelerador. Quando dizemos que um homem pode correr neste sentido de poder (capacidade), e assim com todas as outras coisas que um homem pode fazer, não é suficiente para dizer que, sempre quando outros fatores se combinarem com ele, ele o faz. Podemos pôr a pessoa numa pista, gritar: corre! e nada acontece se ela não quiser. Aqui, por conseguinte, a definição de "H pode fazer F" é um pouco mais complicada, porque acrescenta o fator vontade. Podemos dizer que "H pode fazer $\mathrm{F}=\mathrm{H}$ corre, se (1) tais e tais circunstâncias e (2) se ele quer", mas para abreviar, podemós então deixar as circunstâncias de lado e supor que elas são já pressupostas e assim se chèga à definição

(2) $\mathrm{H}$ pode fazer $\mathrm{F}=$ Def $\mathrm{H}$ faz $\mathrm{F}$ se ele quer.

Ainda que fazer $\mathrm{F}$ năo dependa somente de seu querer, este se pode entender como fator decisivo. Esta definição é a definição à qual Moore chega e corresponde a uma concepçâo que outros compatibilistas, como já Hume, também têm. Aqui podemos dizer depender dèle quer dizer de seu querer e se ele não havia querido, näo o teria feito; ou teria omitido se não tivesse querido.

Mas aqui vêm as criticas. Poderia também não ter querido? Esta pergunta mostra que a definição de Moore é somente uma definição da liberdade da ação: a ação é livre, se depende do querer da pessoa; mas não precisamos de uma definição da liberdade da vontade mesma? O próprio Moore disse que não tinha certeza, se sua definição já é tudo o do que se precisa.

Mas uma segunda crítica, que eu considero mais relevante, è a seguinte: podemos, se somente temos esta definição, verdadeiramente dizer: depende dele? Talvez não, se não podemos dizer em que sentido ele tem o domínio sobre seu querer, e isso talvez equivale à primeira crítica: em que sentido a pessoa é livre em relação ao seu querer? A limitação da definição de Moore consiste em que ela é abrangente demais. Se essa fosse uma definição da imputabilidade, também os 
animais e as crianças pequenas seriam responsáveis por suas açöes. $\mathrm{O}$ conceito de Moore também não permite distinguir a ação imputável de uma ação compulsiva. Nem poderíamos assim entender o conceito de imputabilidade reduzida como de um bêbado: também do bêbado podemos dizer: fez o que queria, e se tivesse querido outra coisa, teria feito outra coisa. Todos estes argumentos visam ao mesmo ponto. Temos que introduzir um fator mais estrito na definiçäo de Moore, temos que distinguir diferentes tipos de vontade. A imputabilidade pressupõe a capacidade não somente de querer, mas de um querer baseado em deliberação. Isso, em princípio, já foi visto por Aristóteles, mas ele não esclareceu de que maneira a deliberaçăo tem que ser incluida. Eu proponho a seguinte definiçăo:

(3) H é imputável $=$ Def $\mathrm{H}$ tem a) a capacidade de deliberar e b) a capacidade de fazer os resultados da deliberação efetivos na sua ação.

Esta definição necessita de dois comentátios. Primeiro, não podemos definir a ação imputável como a ação dirigida pela deliberação, porque a ação da pessoa é naturalmente também imputável quando não está deliberando, mas pode deliberar. Isso indica que precisamos de um critério para poder dizer que pôde ou poderia deliberar. Voltarei depois a este assunto. Segundo: eu incluo o elemento (b) na definição, porque a pura deliberação poderia ser um processo vazio. Existe uma compulsividade de deliberação que consiste neste processo vazio, e se não pode fazer os resultados da deliberação efetivos, isto é claramente o fenômeno da compulsão. Aqui vale a pena usar a terminologia tradicional que encontramos em Kant, quando fala de faculdade superior ou inferior de desejos (ou de querer). Esta faculdade superior de quèrer consiste precisamente num querer baseado na deliberação. $O$ objeto de um querer da faculdade inferior é aquilo que causa prazer ou dor, o objeto do querer deliberativo ou racional é um bem, isso quer dizer que é, ou um meio para um objeto do querer sensível, ou é um querer sensivel, mas agora como que fazendo parte da totalidade dos possiveis objetos de meu querer que posso contemplar na deliberação. ( $\mathrm{O}$ exagero de Kant de falar de um objeto de um querer racional puro naturalmente é desconsiderado.) Estes comentánios sobre um querer racional baseado na deliberação - um querer de um bem - em contraste com um querer simples - tem como conseqüência que podemos reformular a definição (3) correspondentemente. Poderíamos dizer que um homem é imputável, quando é capaz de fazer o que ele acha ser um bem para ele, ou mais claramente, quando ele pode fazer o que acha ser o melhor para ele; isto é exatamente o mesmo que dizer: quando pode deliberar (nos dois passos e que eu expressei com a) e b)).

Existe uma definição de imputabilidade de John Hospers ("What means this Freedom", in: S. Hook, Determinism and Freedom in the Age of Modern Science, 1958) que diz: uma pessoa é imputável no grau em que seu comportamento pode ser mudado por razões. Esta definição é muito próxima á minha (3), porque razões são precisamente os objetivos da deliberação (uma razão neste sentido diz o que é bom para mim), e a definição de Hospers tem a vantagem de dar conta da gradualidade. Imputabilidade é um fenômeno gradual (toda pessoa que agüenta muito álcool, o pode comprovar quando incrementa a dose gradualmente) e no direito penal o conceito de imputabilidade reduzida é importante. 
Pode parecer fácil agora ver como se tem que mudar a definição de Moore à base da definição (3). Moore pretendia que a definiçāo (2) fosse uma definição de ser imputável em ter feito $\mathrm{F}$, mas o que ele definiu é quando se pode dizer que uma ação é voluntária (nem toda ação voluntária é imputável). Em vez da definição de Moore, ter-se-ia que definir agora assim: crito)

(4) $\mathrm{H}$ é imputável enquanto a $\mathrm{F}=\operatorname{Def} \mathrm{H}$ faz $\mathrm{F}$, se querd $\mathrm{F}$. (com um D subs-

$\mathrm{O}$ "D" subscrito significa que se trata de um querer deliberativo. Mas agora a pergunta é importante, se pode quererd F, se é capaz de deliberar. Temos, então, que complementar a definiçăo do seguinte modo:

(5) H é imputável para $\mathrm{F}=$ Def $\mathrm{H}$ faz $\mathrm{F}$ se querd $\mathrm{F}$ e pode quererd $\mathrm{F}$.

Isso nos conduz à pergunta de como podemos saber que o homem pode lou poderia ter) deliberado. Esta pergunta, parece-me, pode ser respondida assim:

(6) $\mathrm{H}$ pode deliberar = em situações que precisam de deliberação, quer dizer, nas quais o homem se encontra diante de uma decisão entre vantagens e desvantagens, $\mathrm{H}$ delibera normalmente. Esta definiçăo é feita análoga a, por exemplo, como se sabe que $H$ pode levantar o pé. Por exemplo, ele se nega a levantar o pé e a pergunta é não o quer ou não pode? Então diríamos: pode, se em outras circunstâncias o faz quando é necessário.

Mas aqui nos deparamos com um problema que parece grave para a psiquiatria e para a lei penal. $O$ caso do poder deliberar não é análogo ao caso do levantar o pé. Parece ser o caso de pessoas que geralmente podem deliberar e nấo o podem diante de um problema especial onde eles são compulsivos. Se é assim, não temos um critério para decidir se devemos dizer que a pessoa não pode ou simplesmente não quer. Isso significa que existem casos, nos quais năo temos um critério para decidir se a pessoa é imputável. Não sei se existe uma forma de solucionar este problema.

Mas voltemos ao problema em geral. As definições 3 e 5 parecem dar uma resposta ao sentido da imputabilidade. A imputabilidade é a característica dos que podem deliberar e a compulsividade é o caso em que esta capacidade é inibida. A liberdade em que consiste a imputabilidade não tem como contrário o comportamento determinado, causado, mas um comportamento causal particular, ao qual a deliberação não tem acesso. Mas a deliberação é igualmente um comportamento causalmente determinado; depende de motivações causadas. Em que grau a pessoa vai deliberar depende, em particular, também do grau e da seriedade em que a pessoa se diz e em que outros the dizem que deve deliberar. Se a pessoa näo continuasse a deliberar, porque sabe que objetivamente está predeterminada se vai deliberar ou não, ocorre um contrasenso. A atitude que ela então adotaria chama-se fatalismo. Fatalismo é a opinião que para o que se faz não faz uma diferença se se delibera ou não. Mas é óbvio que faz uma diferença e que o fatalismo é falso; se eu venho a deliberar porque sou fatalista, isso é uma maneira livre de mudar as coisas e é uma maneira autodestrutiva. Da doutrina que tudo está determinado não segue o fatalismo (quer dizer a renúncia à própria liberdade).

Finalmente, o que pode significar que não somente minha ação é livre, mas que também a vontade deve ser livre? Que significa liberdade da vontade? Creio 
que já antecipei isso com o termo autonomia. Uma motivação que eu tenho vai-se comportar de outra maneira, se a tenho sob controle de minha deliberação: ela, então, năo age cegamente, simplesmente por meio do mecanismo de mais ou menos prazer ou dor, senão é vista como mais ou menos boa; eu posso pôr então a motivação ou o desejo numa relação evalorativa às outras motivações e desejos. O desejo, então, não me determina simplesmente, não me domina, mas eu domino o desejo. O eu é simplesmente o sujeito que delibera. Quando as minhas motivações e desejos nảo funcionam como eu (quer dizer a minha deliberação) o quer, então dizemos, algumas vezes, que eles são mais fortes que eu; esse é o fenômeno da acrasia, da vontade fraca. Parece-me que esse é o único sentido em que podemos dizer que uma motivaçăo é livre; não significa que năo tenha sido causada (nem sei que sentido isso poderia ter), mas que é controlada pela deliberação. Isso permite falar de duas formas em que os desejos não são livies neste sentido: primeiro, quando têm uma efetividade num ser que não pode deliberar, como num animal; segundo, quando têm sua efetividade numa pessoa que, em principio, pode, sim, deliberar, mas está impossibilitada de tê-los sob controle. Em ambos os casos podemos dizer que, então, funcionam em pura causalidade como num paralelogramo de forças, mas isso não quer dizer que a deliberação e tudo que ela faz não sejam causados.

Posso agora confrontar-me com uma critica que Kant fez, na Elucidaçāo da Crítica da razão prática, ao compatibilismo, uma crítica que ele pensou ser tão forte que ele a sublinhou 5 ou 6 vezes e à qual muitos outros se referem para criticar o compatibilismo. Ele diz: "Visto que o tempo passado não está mais em meu poder, cada açăo que pratico tem que ser necessária mediante fundamentos determinantes que não estão em meu poder, isso é, jamais sou livre no momento em que ajo." Se ser livre significasse ser livre da determinação do passado, isso seria assim, mas o ser livre simplesmente é uma maneira de confrontar-me com minhas motivações, e isso posso fazer e devo fazer, ainda sabendo que o meu esforço é totalmente determinado. Só uma coisa não é possivel: năo posso me esforçar, se sei até que grau é determinado que vou poder esforçar-me, porque pertence ao sentido do esforço (de qualquer esforço) de ir tão longe quanto posso; se já sei quão longe posso ir, o meu esforço perde sua tensão. Isso significa que a deliberação, como qualquer outro esforço, não poderia funcionar se soubesse os limites que a predeterminação lhe impôs, mas o conhecimento abstrato que è predeterminado até onde posso ir não tem que inibir em ir tão longe quanto posso. Isso significa: a liberdade psicológica pode muito bem coexistir com a causalidade, também com o saber da causalidade, mas só em abstrato. Isso significa que a pessoa que se comporta deliberadamente pode saber que tudo que está fazendo está predeterminado; mas se por algum milagre a pessoa soubesse concretamente como está predeterminada, ela não poderia deliberar mais. A deliberação e o total conhecimento do meu futuro se excluem. A razão é que temos duas maneiras fundamentalmente diferentes de relacionarmos ao futuro: em orações cognitivas (como "amanhă vai acontecer tal e tal coisa") e em oraçoos intencionais (como "amanhã vou fazer tal e tal coisa"). Se a antecipação cognitiva fosse (o que é naturalmente só uma ficção teórica) tão completa que antecipasse minha intenção, 
então a intenção se faria impossível, e com isso naturalmente também a deliberação, pois a deliberação é simplesmente uma intenção em modalidade de pergunta. Isso não significa que a liberdade é uma ficção, senão que depende de certas condições: se meu conhecimento do futuró fosse tão completo que não pudesse decidir nada, então a decisäo nâo poderia operar, e sobretudio nâo com deliberação. Seria isso o caso de um fatalismo real (em contraste com o fatalismo imaginário do qual falei antes): uma situação da vida humana em que a deliberação não tem sentido. Mas, se não temos a possibilidade da deliberação, toda nossa vida intencional perde seu sentído. Longe de mostrar que a liberdade é uma ficção, isso me parece mostrar de que maneira a liberdade - a capacidade de comportarse deliberadamente - é uma parte integral da nossa existência normal. No caso fictício deste fatalismo real, nos converteríamos em puros espectadores do que ocorre em nós, de maneira algo semelhante à pessoa compulsiva que se vê impotente diante de uma parte de suas motivaçöes; ali como aqui, a pessoa se converte em puro espectador - aqui completo, ali parcial - diante de um jogo puramente causal de forças que a arrastam sem nenhuma possibilidade de ação própria. Isso é talvez o pesadelo errôneo do filósofo que crê que para todo ser causado a liberdade seria impossível. Poder-se-ia dizer, de um modo quase paradoxal, que a liberdade mesma é causada, é um fenômeno causal, mas com isso năo perde suas características. O essencial para mim consiste em darmo-nos conta de que o oposto de ser livre não é o ser necessitado (determinado), mas o ser compulsivo. 